\title{
Cooperation between Russia and India in the Arctic: A pipedream or a strategic necessity
}

\section{J. Bhagwat}

Northern Arctic Federal University named after M. V.Lomonosov, 17, nab. Severnoi Dviny, Arkhangelsk, 163002, Russian Federation

For citation: Bhagwat J. Cooperation between Russia and India in the Arctic: A pipedream or a strategic necessity. Vestnik of Saint Petersburg University. International Relations, 2020, vol. 13, issue 4, pp. 488-506. https://doi.org/10.21638/spbu06.2020.405

The aim of the article is to explore areas of cooperation between Russia and India with specific reference to the Arctic. The Russian Federation has sought strategic partners for the development of the Arctic, with it's primary focus being the development of the oil and gas industry and the Northern Sea Route (NSR). Russia and India have had diplomatic relations in diverse spheres such as space, atomic energy, defense, and the petroleum industry. Russia's focus on the Arctic ushers in many more opportunities for cooperation. India is one of the few countries to which Russia has accorded investment opportunities in the oil and gas and the diamond industry. As a result, India has made significant investments in Russia's oil and gas industry. The article highlights that the energy deficit in India is critical, value of imports is rising and this consequently affects the development of the country. Oil production has been declining marginally and gas production is almost static. There is therefore a need to sign diverse long-term contracts for petroleum products like China has been doing with Russia. The article also suggests that there is a case for increased Indian investment in the Arctic in diverse spheres. The need for greater cooperation in scientific research, development of the NSR and possible utilisation of the enormous technically qualified human resources that India has in diverse areas of the Arctic is noted. The article based upon systemic and comparative analysis concludes that Russia-India cooperation in the Arctic is a strategic necessity.

Keywords: Russia, India, Arctic, natural resources, cooperation.

We the leaders of India and Russia, in the year that marks the $70^{\text {th }}$ anniversary of the establishment of diplomatic relations between our countries note that the Indian-Russian special and privileged strategic partnership is a unique relationship of mutual trust between two great powers [1]

Declaration by the Russian Federation and the Republic of India

\section{Introduction}

The aim of the article is to explore areas of cooperation between Russia and India with specific reference to the Arctic. The analysis will focus on how improved access to natural resources, new trade routes and growing human activity has increased the global impor-

* This article is based upon independent research not funded by any organisation.

(C) St. Petersburg State University, 2020 
tance of the Arctic and this could have a positive impact on the long standing strategic partnership between Russia and India. For countries that border the Arctic Ocean, Russia, the United States, Canada, Norway, and Denmark (through Greenland), an accessible ocean means new opportunities. Prospects of Arctic energy and other natural resources has been one of the key drivers behind increased Arctic attention from polar and nonpolar states [2]. In the theoretical part of the article I will examine the evolution of Russian Federations Arctic strategy and specific policies and plans in support of the strategy. I will also study the initiatives taken by India as an observer state in the Arctic Council. I will then analyse the concrete areas of cooperation possible between the Russia and Indian based upon mutual interests.

The relevance of the research lies in the potential for cooperation between Russia and India in the Arctic region. The purpose of the article is to highlight the potential for cooperation between Russia and India in the Arctic region.

The achievement of this goal is possible when solving the following tasks:

- to analyze the Arctic strategy of Russia. Firstly, is the state of development of key focus areas in the Arctic. Secondly, the desire of Russia to attract investments in the key focus areas;

- India's engagement in the Arctic. This would include India's observer status in the Arctic Council, its Arctic initiatives and its need to get access to Arctic energy and natural resources;

- show the common interests of Russia and India in the Arctic region;

- to emphasize the main trends of possible cooperation between Russia and India in the Arctic.

The object of the research is cooperation between Russia and India in the Arctic.

The subject of research is the development of bilateral cooperation between the

Russia and India in the development of the Arctic. The methodological basis of the research is analysis and synthesis, description and explanation, dialectical approach, systemic and comparative analysis as well as forecasting.

\section{Russia's Arctic Strategy}

In recent decades, Russia has stepped up its earlier nascent efforts to develop the Arctic.

President Putin on 6 March 2020 approved the "Basic Principles of Russian Federation State Policy in the Arctic for the period until 2035" [3, p. 1]. The major differences between this policy document and the previous policy document "Basic Principles of Russian Federation State Policy in the Arctic for the period until 2020" [3, p. 1] are highlighted in Table 1.

Article 12 of the document invites investors to explore the Arctic shelf, set up mineral resource centres and logistic centres connected with the NSR infrastructure and building of icebreaker, SAR and auxiliary fleets [3, p.6]. These would be of interest to Asian Arctic Council observer including India. It also envisages the development of the NSR as an internationally competitive transport corridor [3, p.2]. According to Jorgen Staun, "Russia's strategy in the Arctic is dominated by two overriding discourses which at first glance may look like opposites. On the one hand, an IR [international relations] realism has a clear 
Table 1. Comparison of Russia's national interests in the Arctic as outlined in Basic Principles 2020 and Basic Principles 2035 [4]

\begin{tabular}{|l|l|}
\hline \multicolumn{1}{|c|}{$\begin{array}{c}\text { Basic Principles of Russian Federations' State } \\
\text { Policy in the Arctic till 2020 (adopted in 2008) }\end{array}$} & $\begin{array}{c}\text { Basic Principles of Russian Federations' State } \\
\text { Policy in the Arctic till 2035 (adopted in 2020) }\end{array}$ \\
\hline $\begin{array}{l}\text { To use the Arctic as a strategic resource base to pro- } \\
\text { vide solutions for the problems of social and eco- } \\
\text { nomic development of the country }\end{array}$ & $\begin{array}{l}\text { To ensure Russia's sovereignty and territorial integ- } \\
\text { rity }\end{array}$ \\
\hline $\begin{array}{l}\text { To maintain the Arctic as a region of peace and co- } \\
\text { operation }\end{array}$ & $\begin{array}{l}\text { To preserve the Arctic as a region of peace, with } \\
\text { stable and mutually beneficial partnerships }\end{array}$ \\
\hline $\begin{array}{l}\text { To preserve the unique ecological systems of the } \\
\text { Arctic }\end{array}$ & $\begin{array}{l}\text { To guarantee high standards and prosperity for peo- } \\
\text { ple of the Russian Arctic zone }\end{array}$ \\
\hline $\begin{array}{l}\text { To use the Northern Sea Route as a national trans- } \\
\text { port route for Russia in the Arctic }\end{array}$ & $\begin{array}{l}\text { To develop the Russian Arctic as a strategic resource } \\
\text { base and use it to speed up national economic } \\
\text { growth }\end{array}$ \\
\hline & $\begin{array}{l}\text { To develop the Northern Sea Route as a globally } \\
\text { competitive national transport corridor }\end{array}$ \\
\hline & $\begin{array}{l}\text { To protect the Arctic environment, the principal } \\
\text { homeland and the traditional way of life of the in- } \\
\text { digenous peoples of the Russian Arctic }\end{array}$ \\
\hline
\end{tabular}

patriotic character with winning the Arctic..." [5, p. 4]. Staun argues that "Opposed to this is the IR liberalism, international law-inspired... which is characterised by words such as "negotiation", "cooperation," and "joint ventures". It means that all benefit if they cooperate peacefully. So far, the IR liberalism discourse has been dominating Russian policy in the Arctic" [6, p.314]. This new document reflects a balancing act as it also unequivocally contains the views of the defence ministry: "to ensure Russia's sovereignty and territorial integrity" [3, p. 2]. Laruelle's analysis of the new Arctic strategy states that Russia's vision involves human and financial investments which it cannot rely upon under current budgetary and social circumstances [7, p.7].

\section{India and the Arctic}

India was accorded observer status in May 2013 along with other Asian countries namely, China, Japan, South Korea and Singapore. Unlike China, Japan and South Korea India has not promulgated any Arctic strategy or plans. There is a brief mention of the Arctic on the Ministry of External Affairs website in the form of a focus article [8]. India has focused primarily on scientific research in cooperation with Norway. India's objectives relating to the Arctic have been articulated on the website of the Ministry of Earth Sciences [9]. There has been tardy progress on the polar research vessel which was to be commissioned by 2015-2016 [10] in pursuance of these objectives. This could also indicate lack of budgetary support.

The NITI Aayog is the official think tank of the Government of India. It coordinates the function of the Economic Advisory Council to the Prime Minister of India, which is responsible for policy and future plans [11, p.12]. The NITI Aayog prepares an annual 
report [11, p. 23]. Work has been underway since 2015 on a National Energy Policy until 2030 [11, p. 23]. The "Strategy for New India" promulgated by the NITI Aayog [12, p. 1] may be considered as an official economic strategy of the Government of India in the absence of any other document. However, there is no reference to the Arctic in both these documents. Analysis by international experts have noted unfavourably on the absence of an Arctic strategy by India despite its observer status in the Arctic Council [13, p. 186].

\section{Hydrocarbons and other Resources}

It is projected that the Arctic holds approximately $13 \%$ of the world's undiscovered gas and up to $30 \%$ of the world's undiscovered natural gas supplies, of which $84 \%$ is located in offshore areas [14]. Several internal studies on the potential of hydrocarbon and mineral resources in the Arctic are the basis of policy papers of the Kremlin, examining prospects for immediate and future development [15, p. 14-28]. The revised development strategies of the Russian Arctic are evidence of this focus. By exploiting Arctic resources expected to have $90 \%$ of the hydrocarbon reserves on the entire Russian Continental shelf (66.5\% located in the Western part: the Barents and Kara seas), Moscow will lessen its reliance on diminishing supplies in Western Siberia [16, p. 105]. A recent study has highlighted that the geological exploration of promising mineral resource centers has also been affected; a vital factor is the development of the NSR [17, p. 34-45].

As a result of Western sanctions and the consequent withdrawal of Western Companies from some of the projects, Moscow energetically commenced wooing Asian energy companies to invest in "Arctic LNG 2" [18, p. 16]. According to a study by French political scientist Marlene Laruelle based on data from the International Energy Agency (IEA), the majority of the offshore deposits are not worth exploiting as long as the oil price is fewer than 120 dollars per barrel [19, p. 254] and this has also been noted as USD 100 in other studies $[18$, p. 19; 20]. In 2017, a Russian analyst stated that there would be a further setback in the development of Russian Arctic oil and gas deposits due to the fall in world oil prices and the strained geopolitical situation [21, p. 364].

Russia has revised its Arctic resource development strategy to keep the Arctic energy projects alive [18, p. 16-17]. However, Western experts are of the view that the plan is not economically viable at present oil prices and without foreign partnership [22]. As per the report of the IEA, the production of Arctic oil will be feasible only in the price range of USD 110-120 / barrel [23]. According to another estimate by the IEA, the cost of producing various types of gas: traditional gas; coal bed methane; gas in dense rocks; shale gas; high-sulfur oil gas; Arctic gas; deep-sea gas; the cost of producing Arctic gas is in the range of 4-12 US dollars/ million British thermal units (MMBtu) [24]. Thus, the production of Arctic gas is on the limits of profitability - for the European market, and profitable - for imported gas in Japan (taking into account the costs of LNG transportation) and economically not viable for the North American market [24]. This author could not access any Russian open-source article on the economic feasibility of oil production in the Arctic quoting Russian sources [25, p. 65].

Notwithstanding Western skepticism, Russia continues its relentless march towards exploration of oil and gas and other projects in the Arctic. In the period between 20132019, some large economic projects such as nickel production in Norilsk, commissioning of the Yamal LNG plant, the port of Sabetta and expansion of the infrastructure of the 
Varandey terminal were initiated or completed [26, p. 48]. The Energy Minister Alexander Noval stated in September 2019 that the development and exploration of Russia 's Arctic oil was necessary as Russia was only three years away from peak oil production. He amplified, "We expect about 553 million tonnes of oil production in 2018. We will reach a peak of 570 million tonnes in 2021. Almost half of current capacity could be lost in less than two decades as existing fields pass maturity, with levels expected to drop to 310 million tonnes by 2035” [27].

According to an Oxford Energy study, "the Yamal LNG has been the most successful $L N G$ project in the world during the past decade. Novatek actively promoted by the Russian government brought together an international consortium (see Table 2) comprising one international company with LNG expertise (TOTAL), one major buyer of LNG (CNPC from China) and one major source of finance (Silk Road Fund) whose investment paved the way for Chinese lenders to cooperate with the project" [28, p. 14]. This propelled the project to completion ahead of time and brought in Japanese investment in 2019 for phase 2 of the project.

Table 2. Shareholder structure of Novatek LNG projects [28, p. 14]

\begin{tabular}{|c|c|c|}
\hline \multicolumn{2}{|c|}{ Yamal LNG } \\
\hline Shareholder & Country & Interest (\%) \\
\hline Novatek & Russia & 50.1 \\
\hline Total & France & 20.0 \\
\hline CNPC & China & 20.0 \\
\hline Silk Road Fund & China & 9.9 \\
\hline
\end{tabular}

\begin{tabular}{|c|c|c|}
\hline \multicolumn{2}{|c|}{ Arctic LNG 2 } \\
\hline Shareholder & Country & Interest (\%) \\
\hline Novatek & Russia & 60.0 \\
\hline Total & France & 10.0 \\
\hline CNPC & China & 10.0 \\
\hline CNOOC & China & 10.0 \\
\hline $\begin{array}{c}\text { Japan Arctic LNG } \\
\text { (JOGMEC/ Mitsui) }\end{array}$ & Japan & 10.0 \\
\hline
\end{tabular}

\section{Northern Sea Route}

The political instability in the Persian Gulf and the Middle East may also encourage countries of Northeast Asia to cooperate with Russia in development of the Northern Sea Route (NSR). China has formalized its involvement in the development and exploration of the Arctic by its inclusion of the NSR into a network of maritime passages of the Belt and Road Initiative (BRI) [29, p. 370-395]. A fundamental part of the future Polar Silk Road 
is that the NSR provides easier access for cross-continental shipping in polar waters [30, p.2]. For China particularly, in view of the present dangerous geopolitical situation, with a declared trade war, the threat to the oil producing countries of West Asia, the use of "Pandemic COVID-19" as a form of trade and economic warfare, the threat of blockade since sanctions can be arguably considered as blockade [31, p. 8]; the NSR though it involves a larger financial outlay and creation of the necessary infrastructure, is a safer alternative and strategic route which must be developed along with the land route across Central Asia and Eurasia [32, p. 147-152]. Chinese experts have stated that due to technological, economic, and political reasons, Russia is not able to increase the construction of ships and marine equipment to facilitate Arctic development [30, p.11]. Despite this view, Russia has initiated mega projects for icebreakers allocated to both the Baltisky and Zvezda shipyards in Saint Petersburg and Bolshoi Kamen (Far East) respectively, which includes the biggest nuclear icebreaker ever [33]. Consequently, as sea-ice continues to retreat, the volume of traffic on the NSR will undoubtedly grow especially to and from North East Asia. However, for the reasons identified above, the NSR is unlikely to rival high-traffic maritime routes such as the Suez-Malacca passage in the immediate future.

Realising this and other impediments, President Putin invited investors to assist in the joint construction of the North Sea Route hubs in April 2019 directing the government of the Russian Federation to draw up plans for tax relief that would promote the development of the Arctic region [34]. Russian experts have stated that the development of the NSR is vital to overcoming the weak socio-economic infrastructure in the Arctic [26, p. 50]. In February 2020, the Russian Prime Minister Mikhail Mishushtin announced a legislative package for development of the Arctic. The package includes zero rate of tax on mineral extraction for 12 years and preferential tax regime of $5 \%$ for 15 years to stimulate oil production on the continental shelf [35].

The document "Fundamentals of Russian state policy in the Arctic until 2035" emphasizes that development of the NSR as a globally competitive national transport communication of Russia on the world market is one of the main national interests of the Russian Federation in the Arctic [3, p. 2]. However, sub-para 7(a) notes the decline in the population of the Arctic region and sub-para 7(b) the poor social-economic and transport infrastructure in the region [3, p.3]. In addition, sub-para 7 (e) of the document states that there has been non-compliance with the timelines for creation of infrastructure and building of icebreaker, SAR and auxiliary fleets [3, p.3]. A detailed plan for development of the NSR infrastructure till 2035 was promulgated by the Russian government on 21 December 2019 [36]. A determined effort would be required by the Russian government to ensure funds are made available particularly with low oil prices and the current economic crisis due to COVID-19.

\section{India and the Energy Conundrum}

India is the third largest energy consumer in the world after USA and China. It is dependent on imports for about $82.1 \%$ of its crude oil requirement and to the extent of approximately $44.4 \%$ in the case of natural gas [37, p. 26]. India's crude oil production has continued its decline and for the year 2018-2019 was 34.2 Million Metric Tonnes (MMT) as against the production of $35.68 \mathrm{MMT}$ in $2017-2018$, a decrease of about $4.15 \%$ [38, p. 11]. Import of crude oil during FY 2018-2019 was 226.5 MMT valued at 783,183 crores 


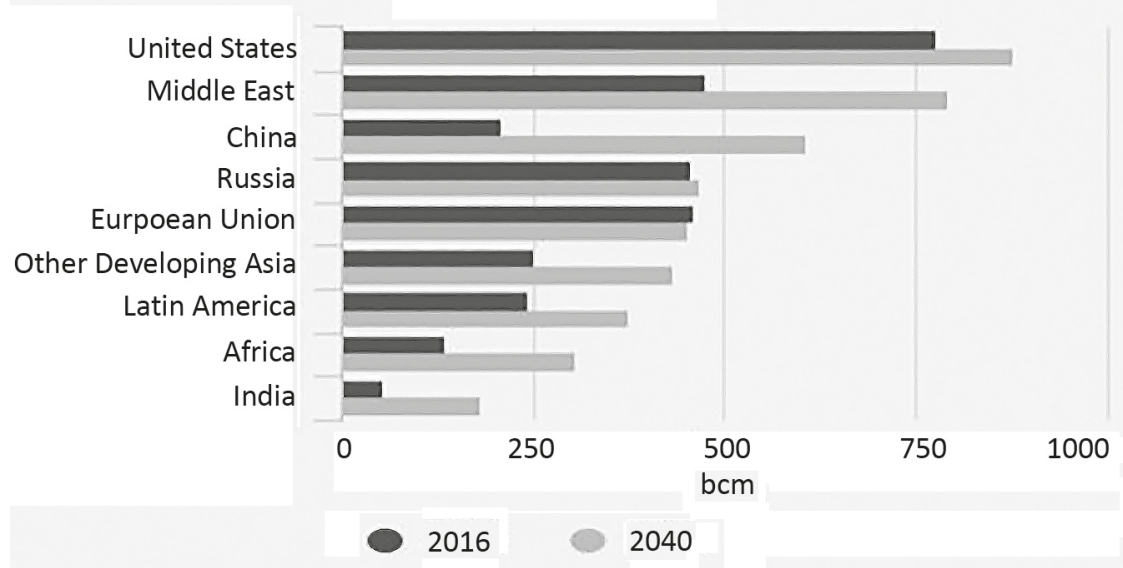

World Energy Outlook 2017. IEA

Fig. 1. Gas demand in selected regions as per World Energy Outlook [40]

\begin{tabular}{|c|c|c|c|c|c|c|c|c|c|}
\hline & \multicolumn{4}{|c|}{$\begin{array}{l}\text { Levels } \\
\text { mboe/d }\end{array}$} & \multirow{2}{*}{$\begin{array}{c}\text { Growth } \\
\% \text { p.a. } \\
2015-2040\end{array}$} & \multicolumn{4}{|c|}{$\begin{array}{c}\text { Fuel shares } \\
\%\end{array}$} \\
\hline & 2015 & 2020 & 2030 & 2040 & & 2015 & 2020 & 2030 & 2040 \\
\hline Oil & 3.9 & 5.0 & 7.3 & 9.9 & 3.7 & 23.3 & 24.0 & 24.4 & 25.2 \\
\hline Coal & 7.6 & 9.5 & 14.0 & 18.1 & 3.5 & 44.9 & 45.9 & 46.8 & 46.4 \\
\hline Gas & 0.9 & 1.1 & 2.0 & 3.0 & 4.9 & 5.3 & 5.5 & 6.8 & 7.7 \\
\hline Nuclear & 0.2 & 0.3 & 0.7 & 1.2 & 7.4 & 1.2 & 1.7 & 2.4 & 3.0 \\
\hline Hydro & 0.2 & 0.3 & 0.5 & 0.6 & 3.6 & 1.4 & 1.5 & 1.5 & 1.5 \\
\hline Biomass & 3.9 & 4.2 & 4.4 & 4.4 & 0.4 & 23.2 & 20.0 & 14.7 & 11.2 \\
\hline Other renewables & 0.1 & 0.3 & 1.0 & 1.9 & 11.3 & 0.8 & 1.4 & 3.3 & 5.0 \\
\hline Total & 16.9 & 20.7 & 29.9 & 39.1 & 3.4 & 100 & 100 & 100 & 100 \\
\hline
\end{tabular}

Fig. 2. India’s primary energy demand by fuel type, 2015-2040 as per World Oil Outlook [41, p. 68]

as against import of 220.43 MMT valued at 566,450 core in 2017-2018 which marked an increase of $2.75 \%$ in quantity terms and $38.26 \%$ in value terms as compared to the import of crude oil during FY 2017-2018 [39, p. 15]. Natural Gas production during the year 2018-2019 was 32.87 billion $\mathrm{m}^{3}$ (BCM), which was only $0.69 \%$ higher than the production of 32.65 BCM in 2017-2018 [39, p. 12]. Import of LNG during 2018-2019 was 21.69 MMT valued at 71,867 core (provisional figures) as against import of 20.71 MMT valued at 52,122 core in 2017-2018 which marked an increase of $4.74 \%$ in quantity terms and $37.88 \%$ in value terms as compared to the import of crude oil during 2017-2018 [39, p. 16-17]. India relies heavily on varied energy suppliers, with most of its imports coming 
from West Asia and Africa. According to the International Energy Agency, India's oil and gas demand is expected to continue its upward trend and expected to double by the year 2040 [38, p. 82] as depicted in Figure 1 and Figure 2, in comparison with other regions of the world.

This diverse web of energy suppliers is, of course, vulnerable to breakages in the supply lines due to political instabilities and other security concerns, and India has tried to meet these challenges by building up a long-overdue Strategic Petroleum Reserve at Visakhapatnam catering for ten days requirement of crude oil [38, p.17]. The Middle East and North Africa, which supply $60 \%$ of India's oil requirements, have witnessed a high degree of geopolitical uncertainty in the recent past. India has made a determined effort to diversify its energy suppliers [38, p. 82]. Therefore, India needs to seek a long-term agreement with Russia for an increased supply of LNG and possibly crude oil on similar lines to the Russia-China agreement for the supply of gas. Russia and China agreed on gas supplies via the Power of Siberia $3000 \mathrm{~km}$ pipeline in 2014, when Gazprom and the China National Petroleum Corporation (CNPC) signed a 30-year contract to deliver 38 billion tons of gas per year by 2025 from Irkutsk and Yakutia [42]. China is expected to become Russia's second-largest gas customer after Germany, which bought 58.5 billion $\mathrm{m}^{3}$ of gas from Russia in 2018 after this pipeline becomes fully operational in 2025 [43]. Russia is now also China's largest oil supplier [44].

\section{Energy Bridge - Russia and India}

Since the Arctic holds the potential of vast energy reserves, there have been discussions on India's participation in the utilisation of Arctic energy. According to Stokke, for India to be able to benefit from these Arctic resources, they would need partners [45, p.770-783]. Russia is India's largest oil and gas investment destination with over US \$ 15 billion investments so far [39, p.76]. India’s state-owned oil company Oil and Natural Gas Corporation Limited's [ONGC] international branch ONGC Videsh Limited [OVL] has invested in Russian energy projects, such as the Sakhalin 1-project in 2002 [46]. In 2015, OVL signed an agreement with the Russian state-owned oil company Rosneft, for investment in the Vankor field in Siberia. As reported in the Indian newspaper Daily News and Analysis, both Russia's President Vladimir Putin and Prime Minister Narendra Modi were present at the signing, and the two oil giants signed a Memorandum of Understanding which emphasized "cooperation for geologic survey, exploration, and production of hydrocarbons onshore and on the continental shelf of the Russian Federation [47]. In 2016, Indian public sector companies invested over US \$ 4 billion in the acquisition of oil and gas production assets in Russia [38, p.76]. In August 2017, Rosneft bought a $49 \%$ share of India's Essar Oil Ltd. Rosneft's investment of nearly \$ 13 billion in the Vadinar refinery is the largest FDI investment in India in the oil and gas sector [39, p. 76]. The deal was Russia's largest ever foreign investment, and India's largest FDI [48]. There is no comparable investment by any other country including the United States, in this vital sector. The various Russian hydrocarbon projects where India has a stake are as tabulated below (see Table 3).

India needs to participate actively in Arctic resource exploration, as the Arctic energy reserves have the potential for a substantial impact on India's energy dynamics. Currently, the world's $11^{\text {th }}$ largest economy (fifth in terms of purchasing power parity as per forecast 
for 2015 according to the IMF, see Figure 3), India could occupy the third slot after the United States and China in 25-30 years, if India manages to sustain her economic growth rate [49].

Table 3. India's involvement in Russian hydrocarbon projects [39, p. 83]

\begin{tabular}{|l|l|}
\hline Name of the Project in Russia & \multicolumn{1}{|c|}{ Participating companies and their share } \\
\hline Sakhalin-1, Offshore & $\begin{array}{l}\text { ONGC Videsh }-20 \%, \\
\text { Exxon Mobil }-30 \% \text { (Operator), } \\
\text { Sodeco }-30 \%, \\
\text { Rosneft subsidiaries - 20\% }\end{array}$ \\
\hline Imperial Energy, Russia & ONGC Videsh $-100 \%$ \\
\hline Vankorneft & $\begin{array}{l}\text { Rosneft }-50.1 \%, \\
\text { ONGC Videsh Vankorneft Pvt. Ltd. }-25 \%, \\
\text { Vankor India Pvt Ltd. - 23.9\% each }\end{array}$ \\
\hline Tass-Yuryakh & $\begin{array}{l}\text { Rosneft }-50.1 \%, \\
\text { British Petroleum }-20.0 \%, \\
\text { Tass India Pvt Ltd. - 29.9\% }\end{array}$ \\
\hline License 61 & OIL $-50 \%$, Petroneft - 50\% \\
\hline
\end{tabular}

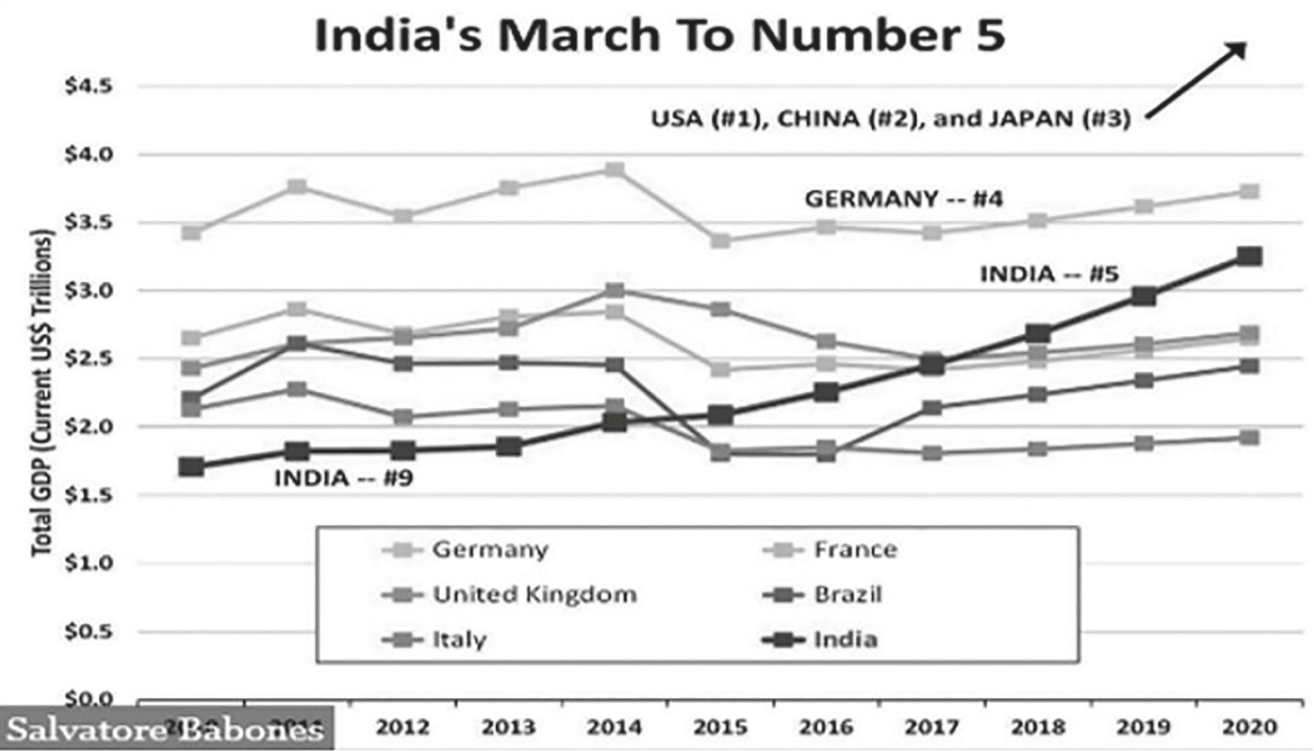

Fig. 3. Growth rate of the World's largest economies (source: IMF) [49] 
As per the World Economic Outlook by the International Monetary Fund, India's growth rate in 2018 was $7.1 \%$, whereas overall world economies grew at an average rate of 3.3$3.6 \%[50$, p. 18$]$.

\section{Russia and India Strategic partnership}

Russia has historically been an important partner for India in the spheres of atomic energy, space and military equipment. Despite India being one of the leaders of the nonalignment movement, ties between the then Soviet Union and India progressed through extensive bilateral engagements [51, p. 6-7]. Russia has also been India's time-tested partner in the oil and gas sector. In the 1970s a team of Soviet oil and gas experts helped ONGC in the discovery of Bombay High, which even today remains India's biggest oil and gas field [38, p. 76]. During the period of the political disintegration of the Soviet Union in the 1990s, ties between India and (now) Russia were slightly less prioritized from Russia's side due to internal and external political challenges [51, p.7]. In India too, there began an unstated 'Look West' policy later balanced by a 'Look East' policy as well, which impacted the earlier close friendship.

After the signing of "Declaration on the India-Russia Strategic Partnership" during the visit of Russian President Vladimir Putin to India in October 2000, India-Russia ties acquired qualitatively a new character with enhanced levels of cooperation in almost all areas of the bilateral relationship including diplomatic, security, trade, economy, defense, science and technology, and culture [52]. During the visit of the Russian President to India in December 2010, this Strategic Partnership was elevated to the level of a "Special and Privileged Strategic Partnership" [52]. Both sides have taken significant initiatives to achieve the ambitious trade target of US \$ 25 billion set for 2025 [53, p. 95]. However, this target is an order of magnitude smaller than the India-China or India-US trade figures. Russia's share in India's exports was only $0.73 \%$ (the US \$ 2.4 billion) for the period 20182019 as compared to $15.88 \%$ for the United States (the US \$ 52.43 billion) and $5.08 \%$ (the US $\$ 16.75$ billion) for China [50, p. 27-29, 73-85]. Concerning imports, Russia's share was only $1.14 \%$ (the US $\$ 5.8$ billion) for the period 2018-2019 showing a decline of $31.88 \%$ from $2018-2019$ figures (the US $\$ 8.5$ billion) as compared to $6.92 \%$ (the US \$ 35.55 billion) for the United States and $13.68 \%$ (the US \$ 70.32 billion) for China [50, p. 27-29, 73-85]. Katherine Foshko succinctly stated, "As is increasingly recognized, the deficiencies of Indo-Russian trade, as well as most of the other pillars of the relationship are linked to the heavy involvement of the state - and the absence of energetic engagement from the private sector. The state sector alone cannot influence the development of trade in a globalizing increasingly competitive market" [54, p. 144]. There is much potential for the exchange of high technology for peaceful purposes.

Article 85 of the concept of Foreign Policy for the Russian Federation (2016) states unequivocally, "Russia looks at further deepening the special privileged relationship with India based upon congruent external political priorities, historical friendship and deep mutual trust" [55, RF., India, p.31]. As stated in the Saint Petersburg declaration, "The economies of India and Russia complement each other in the energy sector. We will strive to build an "Energy Bridge" between our States and expand bilateral relations in all areas of energy cooperation, including nuclear, hydrocarbon, hydel, and renewable energy sources, and in improving energy efficiency... We are interested in launching joint projects on exploration 
and exploitation of hydrocarbons in the Arctic shelf of the Russian Federation [1]." Both countries need to encourage greater vitality and cooperation in the corporate sphere [54, p. 144].

Russia invited Indian Prime Minister Narendra Modi to the Eastern Economic Forum at Vladivostok in September 2019 as the chief guest [56]. Post talks with the Indian Prime Minister, the Russian President stated at a press conference, "Indian energy concerns are invited to participate in projects such as Far Eastern LNG and Arctic LNG 2" [56]. The two leaders also proposed to develop a full-fledged maritime route between Vladivostok and Chennai. In 2012, GAIL had already signed a 20-year contract with Gazprom for the supply of 2.5 million tons of LNG per year. In January 2018, Gas utility GAIL (India) Ltd renegotiated the terms of a long-term liquefied natural gas (LNG) purchase deal with Russia's Gazprom [57]. The first cargo of Russian LNG was received on June 04, 2018 [38, p. 76]. However, unlike France, China and Japan, India has so far not invested in the Arctic LNG 2 project. The Indian Minister of Commerce and Industry expressed the hope that Russia and India could jointly develop the Northern Sea Route [56].

\section{Gas and Oil Wars?}

The OPEC World Oil Outlook 2018 stated that almost $95 \%$ of the increase in the total primary energy demand is likely to be accounted for by developing countries (including China and India) with an average annual growth of $1.9 \%$ p.a. over the forecast period till 2040 [41, p. 57]. It evident from the above analysis that relations with Russia are closer in the energy sphere due to India's commitment to diversify its energy imports in the context of US sanctions on the Iranian energy industry. The Ministry of Petroleum and Natural Gas, India and GAIL need to study the examples of Japan [58] (world's largest LNG buyer) and Germany, who though close security partners of the United States, have continued their energy links with Russia despite the threat of US sanctions. In response to President Trump's remark in July 2018, "Germany, as far as I am concerned, is captive to Russia because it's getting so much of its energy from Russia", Chancellor Angela Merkel retorted diplomatically, "we can make our policies and our own decisions [59]." It is well known that these sanctions are due to competing commercial interests [60] as the United States is the world's largest natural gas producer, and Russia is the second world's largest natural gas producer and holds the world's largest gas reserves [61].

A study carried out by a team of researchers from Murmansk State Technical University, Murmansk, Russia and Federal Research Center «Kola Science Center of the Russian Academy of Sciences», Apatity, Russia with reference to calculations of costs for Arctic gas transportation to Germany, Italy, Turkey and China demonstrated that "sea transportation of $1,000 \mathrm{~m}^{3}$ of natural gas is cheaper than pipeline transportation by the average value of 106.3 USD (-40.2\%) across all the routes (including Suez canal and the Northern Sea Route) in question (see Table 4). The calculations proved the economic benefits of sea transportation of Arctic LNG to the existing and potential markets for natural gas" [62, p. 554-559]. This study needs to be examined in detail by GAIL whilst carrying out a cost benefit analysis of purchasing LNG from different sources.

In March 2020, there was disagreement between Russia and Saudi Arabia on production cuts at the OPEC + forum (see Figure 5 for oil exports of Russia, Saudi Arabia and the USA) that exacerbated tensions in the oil industry and stoked a price and share war 
between them. By the time, the two energy rivals downplayed differences and signed an agreement; the COVID-19 pandemic went on the rampage to trigger concerns in the US crude markets (see Figure 5). US President Donald Trump claimed to have brokered the deal 2024 [64]. However, what was not highlighted that the United States and Canada also agreed to be part of the production cuts. Therefore, according to this author the recent drop in oil prices as a result of supply glut brought about by the COVID-19 pandemic and the impact of the initial non-agreement on crude oil production quotas may be a temporary phenomenon as the US oil and gas industry will not survive if crude oil prices go below USD 30 per barrel 2024 [65]. Oil prices had recovered to USD 40 by September $2020[66]$.

Table 4. Comparison between the costs of pipeline transportation and sea shipment of natural gas (USD/ $1000 \mathrm{m3}$ ) [62, p. 557]

\begin{tabular}{|l|c|c|c|c|}
\hline \multirow{2}{*}{\multicolumn{1}{|c|}{ Transportation route }} & \multicolumn{2}{|c|}{ Pipeline transport } & \multicolumn{2}{c|}{ Sea shipment } \\
\cline { 2 - 5 } & $\begin{array}{c}\text { Distance km } \\
\text { (average) }\end{array}$ & $\begin{array}{c}\text { CPpipeline } \\
\text { (average) }\end{array}$ & Sea shipment & $\begin{array}{c}\text { CPlng } \\
\text { (average) }\end{array}$ \\
\hline South Tambey - Germany & 4270 & 235.84 & 4700 & 152.98 \\
\hline South Tambey - Germany & 5570 & 279.38 & 8840 & 152.06 \\
\hline South Tambey - Turkey & 5720 & 293.95 & 10330 & 153.56 \\
\hline $\begin{array}{l}\text { South Tambey - China } \\
\text { through Suez Canal }\end{array}$ & 7370 & 247.60 & 24000 & 165.00 \\
\hline $\begin{array}{l}\text { South Tambey - China across } \\
\text { the NSR }\end{array}$ & 7370 & 247.60 & 11600 & 151.00 \\
\hline
\end{tabular}

Note: The cost of piping $1000 \mathrm{~m}^{3}$ of natural gas across $100 \mathrm{~km}$ via the Power of Siberia pipeline is approximately 6.3 USD, via major Chinese pipelines - 2 USD.

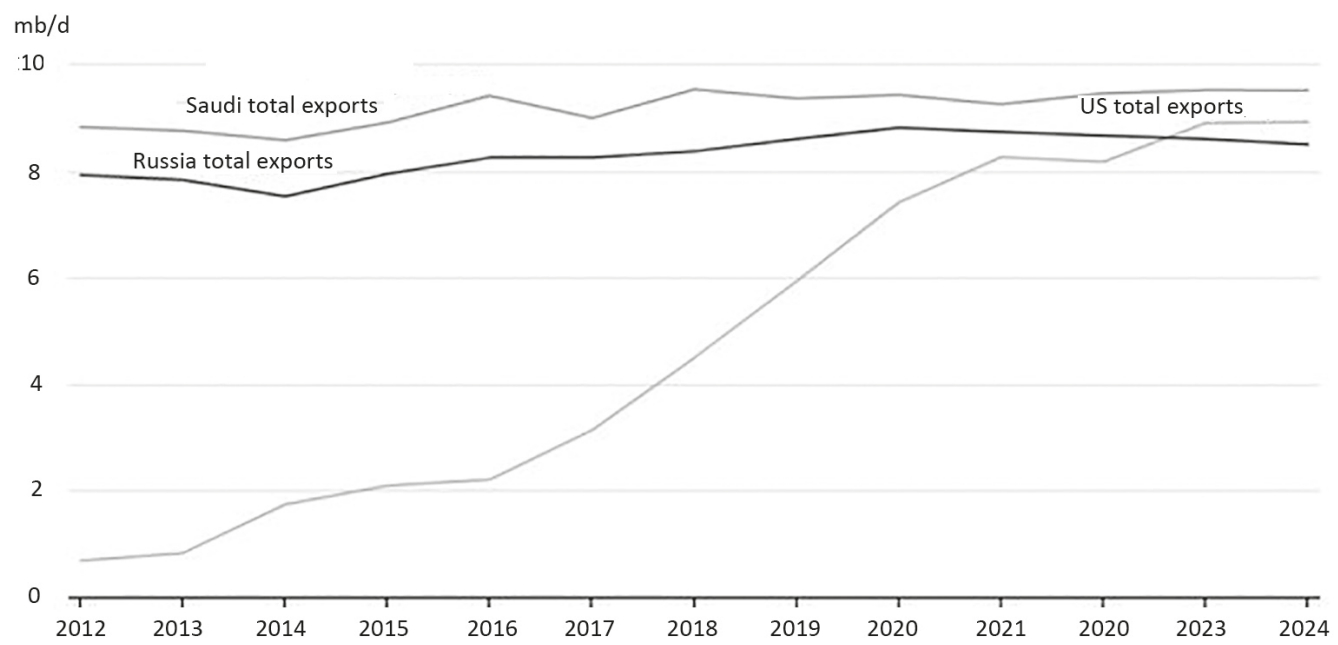

Fig. 4. Gross oil exports for selected countries 2012-2024 [63] 


\section{US oil goes negative for the first time}

Oil prices fell below $\$ 0$ as demand plummets and America runs out of room to store barrels of crude.

- Light crude (May contract)

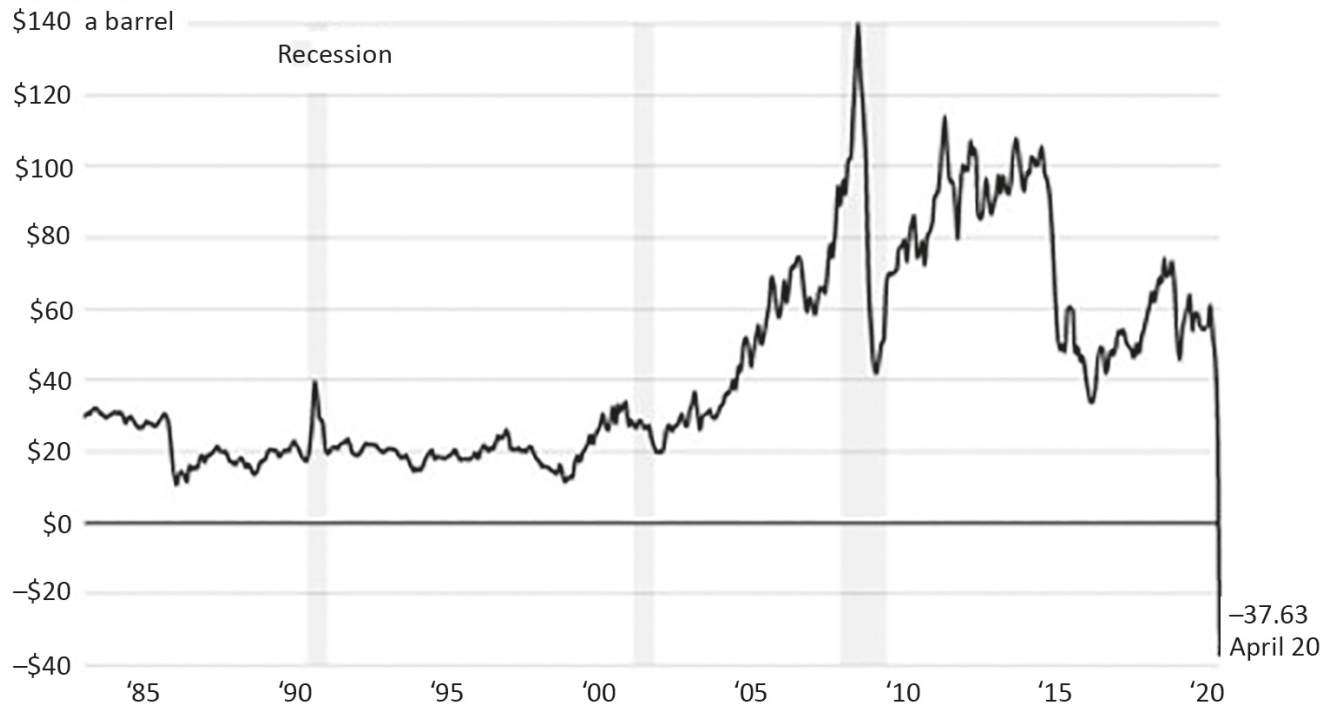

Source: Refinitiv

Grapfic: Tal Yellin, CNN

Fig. 5. US oil goes negative for the first time [66]

According to the IEA, global capital expenditure by exploration and production companies in 2020 is forecast to drop by about $32 \%$ versus 2019 to $\$ 335$ billion, the lowest level for 13 years [67]. Oil price volatility is one of the key factors affecting the exploitation of Arctic offshore oil and gas resources [68, p.8]. India has developed some expertise in the exploitation of offshore hydrocarbons in shallow waters of up to 50 metres, though in far more benign geographical and geological conditions. Russia has had to rely on foreign companies to carry out some geological work in the Arctic [69, p. 115-124]. Other than investments, for India it may be worthwhile to have our petroleum experts assist Russia in offshore exploration and extraction. However, at this stage due to depressed global oil prices it would be premature for India to invest in Arctic offshore oil exploration. Notwithstanding, Arctic energy, specifically LNG, which presently only accounts for $6.2 \%$ of India's primary energy mix [39, p.46] forms a vital key component to propel India's economic growth further since consumption itself is linked with growth. Besides, the Arctic is a rich source of strategic minerals, diamonds and timber, which are essential for the rapidly growing Indian economy.

Climate change is another area of concern for India. Researcher UK Sinha aptly stated that "The contemporary Arctic expresses an 'antithetical situation' [70, p. 38-39] with economic and commercial interests on the one end and a need for mitigating climate risks and resource governance at the other" [71, p. 126]. There is a view amongst some Indian Arctic experts that India should not be involved in the Arctic due to environmental risks. As stated in the Saint Petersburg declaration, "India and Russia note the wider use of 
natural gas, an economically efficient and environmentally friendly fuel, which has become an integral part of the global energy market is highly significant for reducing greenhouse gas emissions and will assist in fulfilling the provisions of the Paris agreement on Climate Change, as well as achieving sustainable economic growth" [1]. There is a, therefore, a need for both countries to transit from fossil fuels to LNG and renewable energy at a more rapid rate. India aims to achieve a share of $15 \%$ for LNG as part of the primary energy mix [39, p. 46]. In Arkhangelsk Oblast, for example, the possibility of utilization of wind and solar energy to a lesser extent exists. India has developed a reasonable amount of expertise in renewable energy, which could be utilized by Russia.

Scientists are increasingly predicting that the Arctic could be ice-free in summer by 2035 [72, p. 1043]. Another study stated that no matter what steps are taken by countries to limit emissions this would be almost certain by 2050 [73]. The United States National Snow and Ice data Center reported that on September 15, 2020 was observed the second lowest Arctic sea ice extent on record [74]. These would need to be taken into account by India, which needs to formulate a pragmatic Arctic policy balancing various conflicting interests.

\section{Other Areas of Cooperation in the Arctic}

India has substantial experience in research in Antarctica. In the Arctic, its research efforts began only in 2007. Since then it has been cooperating mainly with Norway. India's scientific interaction with Russia has been limited despite the Saint Petersburg declaration that "We will develop joint strategies to harness for mutually beneficial cooperation in the field of deep-sea exploration and development of hydrocarbon resources, polymetallic nodules, and other marine resources utilizing strengths in the fields of maritime research and training to develop mutually beneficial cooperation." Presently there is no cooperation either at the level of the National Centre for Polar and Ocean Research (NCPOR) or any other university. M. Ravichandran, Director, National Centre for Polar and Ocean Research (NCPOR), India's premier research institution responsible for the country's research activities in the polar (Arctic, Antarctica, Himalayas) and Southern Ocean realms stated the ongoing COVID-19 crisis may foster dialogues on bolstering cooperation between nations. "We are collaborating with different nations in polar research but we need to have more collaboration with them. For example, near our stations on Antarctica, Russian stations are present and they help us out and we help them out as well. But there may be more discussions on how to scale up the collaborations" [75].

As the Navigation Area-VII coordinator, India has substantial expertise in carrying out hydrographic surveys and the preparation of electronic charts for nations of the IOR. Though hydrography is generally a restricted area, if Russia seeks assistance, India could cooperate in the preparation of electronic charts for the Northern Sea Route, which presently have restricted availability [31, p.21].

\section{Recommendations for Russia-India Cooperation in the Arctic}

In view of the above, India needs to deepen the collaborative relationship with Russia with specific reference to the Arctic. Salient recommendations concerning a framework for India - Russia cooperation in the Arctic region, which may be taken into account by 
the conveners of the India-Russia inter-governmental commission Trade, Economic, Scientific, Technological and Cultural Cooperation (IRIGC-TEC), are as follows:

(a) The Indian government needs to formulate a realistic Arctic policy respecting the rights of the Arctic states under Article 234 of UNCLOS. This policy should include areas of cooperation with the Arctic littoral states and India needs to accord priority to its partnership with Russia.

(b) India may consider a joint venture with other Asian Arctic Council observer states such as China, Japan, the Republic of Korea, and Singapore to set up transshipment hubs along the NSR.

(c) The Indian government has given the in-principle approval for the procurement of a polar research vessel, and the Ministry of Earth Sciences and National Centre for Polar and Ocean research could examine cooperating with Russia in the acquisition of this vessel.

(d) Acquisition of at least one Arc 7 ice-class LNG tanker by the Shipping Corporation of India [SCI], which will enable LNG to be transported throughout the year without the assistance of icebreakers. This needs to be combined with the training of human resources critical for navigation and ship-handling in the polar Arctic region for the arduous transit from Russia's Far North to India and transits of merchant vessels using the NSR, for which India will need the assistance of Russia.

(e) India has highly qualified human resources, which has the potential to contribute to various projects in the Arctic region. This in turn could benefit the overall development of the country and generate employment opportunities for different sectors in the economy.

(f) A collaborative relationship with Russia in terms of scientific research is at a nascent stage, and this could be strengthened. According the NCPOR, Polar University status and having a partnership with the Northern Arctic Federal University at Arkhangelsk would be a welcome step forward. Organizing a joint seminar to examine areas of cooperation would be another step in the right direction. Sending of a research scholar to the Northern Arctic Federal floating university ship also could be an essential component of the cooperation in scientific research.

(g) India needs to be actively concerned that the melting Arctic ice may affect us as a peninsular coastal nation, both due to rising sea levels and the possible collateral effects of global climate change. A joint research project with Russia on climate change could be initiated.

(h) India could contribute to Russia's development of the Arctic with its experience and expertise in renewable energy.

(i) India's strategic energy policy needs to take into account the energy resources of the Arctic. There is, therefore, a need for ONGC or GAIL to invest in projects such as the Arctic LNG 2 project subject to a detailed cost-benefit analysis with respect to LNG supplies from other sources as specific offers have been made to India in this regard by the Russian Federation. Presently, oil prices do not permit investment in offshore assets.

(j) Formulate long-term contracts for petroleum products, strategic minerals and timber with the Russian Federation. 
(k) Russia needs to examine possibilities of importing more Indian products and services, especially to the Arctic region.

(l) India has substantial knowledge in hydrographic surveys and preparation of electronic charts to IMO standards, which may be of interest to the Russian side.

\section{Conclusion}

It is widely accepted by most experts that Russia needs enhanced cooperation and financial investment from other countries to develop the Arctic. Post 2014, this is likely to be forthcoming mainly from Asian countries in view of Western sanctions and favourable conditions for investors. Russia actively seeks the partnership of interested Asian countries including India. India has a unique opportunity to take advantage of its strategic partnership with Russia and cooperate with it in diverse spheres such as energy, development of the NSR, mineral resources, timber industry, renewable energy, acquisition of a polar research vessel, exchange of highly qualified manpower, scientific research on climate change and institutional linkages between Russian universities and the NCPOR. The article based upon systemic and comparative analysis concludes that Russia-India cooperation in the Arctic is mutually advantageous; it is a strategic necessity for both countries given the challenging state of the global economy and a need to revive both the economies for the social-economic development of the people of both countries.

\section{References}

1. Saint Petersburg Declaration by the Russian Federation and the Republic of India: A vision for the 21st centur (2017), June 1. Available at: http://en.kremlin.ru/supplement/5199 (accessed: 01.07.2020).

2. Weir, F. (2007), As Icecap melts Russia Races for Arctic resources, July 31. Available at: https://www. csmonitor.com/2007/0731/p01s01-woeu.html (accessed: 01.05.2020).

3. About the Basic Principles of Russian Federation State Policy in the Arctic to 2035, Order of the President of the Russian Federation, 2020, March 5, no. 164. Available at: http://prezident.org/articles/ukaz-prezidenta-rf-164-ot-5-marta-2020-goda-05-03-2020.html (accessed: 06.03.2020). (In Russian)

4. Klimenko, E. (2020), Russia's New Arctic Policy Document Signals Continuity rather than Change, SIPRI, March 27. Available at: https://www.sipri.org/commentary/essay/2020/russias-new-arctic-policydocument-signals-continuity-rather-change (accessed: 27.03.2020).

5. Staun, J. (2015), Russia's Strategy in the Arctic. Copenhagen: Royal Danish Defence College, Institute for Strategy.

6. Staun, J. (2017), Russia's Strategy in the Arctic: cooperation, not confrontation, The Polar Record, vol. 53, iss. 3, pp. 314-332.

7. Laruellle, M. (2020), Russia’s Arctic Policy. A Power Strategy and its Limits, Russie.Nei.Visions, no. 117.

8. India and the Arctic (2020), June 10. Available at: https://mea.gov.in/in-focus-article.htm?21812/ India+and+the+Arctic (accessed: 27.07.2020).

9. Indian Scientific Endeavours in the Arctic (2018), August 14. Available at: https://moes.gov.in/programmes/indian-scientific-endeavors-arctic (accessed: 27.03.2020).

10. Polar Research Vessel (2018), August 14. Available at: https://moes.gov.in/programmes/constructionpolar-research-vessel (accessed: 27.07.2020).

11. NITI Aayog (2020), Annual Report 2019-20. New Delhi: NITI Aayog.

12. NITI Aayog (2018), Strategy for New India. New Delhi: NITI Aayog.

13. Zhuravel, V.P. (2017), Russia and the Asian Countries of the Arctic Council: Problems of Interaction, in Proceedings of the second international conference: Arctic: History and Modernity, Saint Petersburg Technical University named after Peter the Great, Saint Petersburg, 2017, April 19-20. Место изд.?, рр.179-191. (In Russian)

14. USGS Factsheet 2008-2049 (2008), US Geological Survey Fact Sheet, July 23. Available at: https:// pubs.gov/usgs-factsheet/2008-2049 (accessed: 27.07.2020). 
15. Prishchepa, O. M., Metkin, D. M. and Borovikov, I. S. (2019), Hydrocarbon Potential of the Russian Arctic Area - Prospects and the Future Developmen, Mineral Resources of Russia. Economics and Management, no. 3, pp. 14-28. (In Russian)

16. Zysk, K. (2010), Russia’s Arctic Strategy: Ambitions and Constraints, Joint Force Quarterly, iss. 57, pp. 103-110.

17. Mashkovtsev, G. A., Sporykhina, L. V. and Bykhovskiy, L.Z. (2019), The Condition, Prospects of Use and Development of the Ore Mineral Raw Materials Base of the Russian Arctic Zone, Mineral Resources of Russia. Economics and Management, no. 3, pp. 34-45. (In Russian)

18. Shapovalova, D., Gallimulin, E. and Grushevenko, E. (2020), Russian Arctic offshore petroleum governance. The effects of Western sanctions and outlook for Northern development, Energy Policy, vol. 146, pp. 1-36.

19. Laruelle, M. (2014), Resource, State Assertion and International Recognition: Locating the Drivers of Russia's Arctic Policy, The Polar Journal, vol. 4, no. 2, pp. 253-270.

20. Aalto, P. (2016), Modernisation of the Russian Energy Sector: Constraints on Utilising Arctic Offshore Oil Resources, Europe-Asia Studies, vol. 68, no. 1, pp. 38-63.

21. Katysheva, E. G. (2017), Assessment of the Prospects for the Development of Oil and Gas Projects on the Arctic Shelves of Russia, in Proceedings of the second international conference: Arctic: History and Modernity, Peter the Great Saint Petersburg Polytechnical University, Saint Petersburg, 2017, April 19-20. Место изд.?, pp. 361-369. (in Russian)

22. Alegre, M. et al. (2015), Challenges and Opportunities of Oil and Gas Investment in the Arctic, Columbia University School of International and Public Affairs. Available at: https://sipa.columbia.edu/file/6033/ download?token=8VIcH_DS (accessed: 01.05.2020).

23. World Energy Outlook 2013. Available at: https://www.iea.org/reports/world-energy-outlook-2013 (accessed: 01.05.2020).

24. Resources to Reserves 2013: Oil, Gas and Coal Technologies for the Energy Markets of the Future. https://doi.org/10.1787/9789264090705-en.

25. Shvets, N.N. and Beresneva, P.V. (2014), Oil and Gas Resources of the Arctic: Legal Status, Resources Estimation and Economic Feasibility of Their Development, Vestnik MGIMO-Universiteta, vol. 4, iss. 37, pp. 60-67. (In Russian)

26. Grinyaev, S. N. and Zhuravel, V.P. (2020), Integrated Security Issues in the Basic Principles of Russian Federation State Policy in the Arctic to 2035: Experience and Prospects for Implementation, Arctic and North, no. 39, pp. 52-74.

27. Novak: Oil production may fall $44 \%$ by 2035 (2018), September 18. Available at: https://tass.ru/ ekonomika/5576235 (accessed: 01.05.2020). (In Russian)

28. Russian LNG: Becoming a Global Force (2019), November 2019. Available at: https://www.oxfordenergy.org/wpcms/wp-content/uploads/2019/11/Russian-LNG-Becoming-a-Global-Force-NG-154.pdf (accessed: 21.05 .2020$)$.

29. Zhang, X. (2019), Regional Aspects of the Arctic Ice Silk Road: Case of Heilongjiang Province, China, in Handbook of Research on International Collaboration, Economic Development, and Sustainability in the Arctic, ed. by Erokhin, V. and Tianming, G. Hershey, Pennsylvania: IGI Global

30. Tianming, G. and Erokhin, V. (2019), China-Russia collaboration in Shipping and Marine engineering as one of the key factors of secure navigation along the NSR, The Arctic Yearbook, Arctic Centre, University of Arctic, Место изд.? pp. 1-20.

31. Bhagwat, J. (2020), Maritime Shipping on the Northern Sea Route: Need for Greater Emphasis on Mutual Cooperation and a Non-Negotiable Safety Culture. Part I, Arctic and North, no. 39, pp. 5-25.

32. Xieuwen, S. (2017), Oil and Gas Resources of the Arctic: Legal Status, Resources Estimation and Economic Feasibility of Their Development, Vestnik of Lomonosov Moscow State University. International Relations and World Politics, vol. 2, no. 25, pp. 134-169. (In Russian)

33. Digges, C. (2020), Russian Officials Remotely ink Contract to build Biggest Nuclear Icebreaker Ever, May 1. Available at: https://bellona.org/news/arctic/2020-05-russian-officials-remotely-ink-contract-tobuild-biggest-nuclear-icebreaker-ever (accessed: 02.05.2020).

34. Putin invites foreign investors to help build Northern Sea Route hubs (2020), April 9. Available at: https://www.arctictoday.com/putin-invites-foreign-investors-to-help-build-northern-sea-route-hubs/ (accessed: 02.05.2020).

35. Northern Sea Route Information Office, News Review of the Events on the NSR (2020), February 1. Available at: https://rtic-lio.com/news-review-of-the-events-on-the-nsr1-february-2020 (accessed: 02.05.2020). 
36. Plan for Development of the Northern Sea Route until 2035: Order of the President of the Russian Federation, 2019,December 21, no. 3120. Available at: http://government.ru/docs/38714/ (accessed: 31.07.2020). (In Russian)

37. Ministry of Petroleum and Natural Gas (2018), Annual Report 2017-18. New Delhi: Ministry of Petroleum and Natural Gas, 2018.

38. Ministry of Petroleum and Natural Gas (2019), Annual Report 2018-19. New Delhi: Ministry of Petroleum and Natural Gas, 2019.

39. Ministry of Petroleum and Natural Gas (2020), Annual Report 2019-20. New Delhi: Ministry of Petroleum and Natural Gas, 2020.

40. Gas Demand in Selected Regions, World Energy Outlook 2017. Available at: http://www.iea.org/publications/freepublications/publication/OilInformation2017Overview.pdf (accessed: 31.07.2020).

41. Organisation of Oil Petroleum Exporting Countries (2018), World Oil Outlook 2040. Austria: Organisation of Oil Petroleum Exporting Countries.

42. Putin and Xi to launch strategic natural gas pipeline from Russia to China in December (2019), November 12. Available at: http://www.rt.com/business/473218-putin-xi-power-of-siberia (accessed: 31.07.2020).

43. Russia, China launch gas pipeline 'Power of Siberia' (2019), December 2. Available at: http://m. dw.com/en/russia-china-launch-gas-pipeline-power-of-siberia/a-51500187 (accessed: 31.07.2020).

44. Hsiung, C. W. (2020), The Emergence of a Sino-Russian Economic Partnership in the Arctic, May 19. Available at: https://www.thearcticinstitute.org/emergence-sino-russian-economic-partnership-arctic/ (accessed: 31.07.2020).

45. Stokke, O. S. (2014), Asian Stakes and Arctic Governance, Strategic Analysis, vol. 38, no. 6, pp. 770783.

46. Taneja, K. (2015), China and India Go Arctic, August 14. Available at: http://www.politico.eu/article/ china-and-india-go-arctic-sanctions-gas-oil-explorationlng (accessed: 11.07.2020).

47. Blank, S. (2018), India's Arctic energy partnership with Russia, October 24. Available at: http://www. lowyinstitute.org/the-interpreter/indias-arctic-energy-partnership-russia (accessed: 11.07.2020).

48. \$12.9 bln Essar Oil deal with Rosneft-led consortium concluded (2017), August 22. Available at: https:// neftegaz.ru/en/analisis/mergers/441203-129-bln-essar-oil-deal-with-rosneft-led-consortium-concluded10-things-to-know/ (accessed: 11.07.2020).

49. Babones, S. (2017), India is poised to become the World's Fifth Largest Economy, Forbes, December 27. Available at: https://www.forbes.com/sites/salvatorebabones/2017/12/27/india-is-poised-to-becomethe-worlds-fifth-largest-economy-but-it-cant-stop-there/ 6bf578213ff1 (accessed: 01.07.2020).

50. Ministry of Commerce (2019), Annual Report 2018-19. New Delhi: Ministry of Commerce.

51. Sen, R. (2011), The Evolution of India's Relations with Russia. New Delhi: Aspen Institute of India.

52. Ministry of External Affairs, India (2020), India's Relations with Russia, June. Available at: https:// www.mea.gov.in/Portal/ForeignRelation/India_Russia_Jun_2020.pdf (accessed: 21.07.2020).

53. Ministry of External Affairs (2020), Annual Report 2019-20. New Delhi: Ministry of External Affairs.

54. Tsan, K. F. (2012), Re-Energising the Indian-Russian Relationship, Jindal Journal of International Affairs, vol. 2, iss. 1, pp. 140-184.

55. About the Concept of Foreign Policy of the Russian Federation. Order of the President of the Russian Federation, 2016, November 30, no. 640. Available at: http://prezident.org/articles/ukaz-prezidenta-rf164-ot-5-marta-2020-goda-05-03-2020.html (accessed: 06.03.2020). (In Russian)

56. Devyatkin, P. (2019), Russia and India set to deepen Trade and Investment in Arctic Energy, September 5. Available at: https://www.highnorthnews.com/en/russia-and-india-set-deepen-trade-and-investment-arctic-energy (accessed: 06.03.2020).

57. Verma, N. and Vukmanovic, O. (2018), India’s GAIL reworks Gazprom LNG deal, Reuters, January 16. Available at: https://www.reuters.com/article/gail-gazprom-lng/update-2-indias-gail-reworksgazprom-lng-deal-raises-volume-idUSL3N1PB484 (accessed: 06.04.2020).

58. Ryosuke, Hanafusa (2019), Japan and Russia set to launch $\$ 9^{\text {bn }}$ LNG project in Far East, December 20. Available at: https://www.asia.nikkei.com/Business/Energy/Japan-and-Russia-set-to-launch-9bn-LNGproject-html (accessed: 06.04.2020).

59. Karasz, P. (2018), Germany Imports gas From Russia. But Is It a 'Captive', New York Times, 11 July. Available at: https://www.nytimes.com/2018/07/11/world/europe/trump-germany-russia-gas-html (accessed: 06.04.2020).

60. Salamah, M. (2017), Gas Wars?, June 29. Available at: https://www.globalresearch.ca/gaswars/559672-html (accessed: 06.05.2020). 
61. Mikovic, N. (2020), Energy-poor Europe torn between Russian and American gas, February 4. Available at: https://www.globalcomment.com/energy-poor-europe-torn-between-russian-and-american-gashtml (accessed: 06.05.2020).

62. Kozmenko, S., Masloboev, V. A. and Matviishin, D. A. (2018), Justification of Economic Benefits of Arctic LNG Transportation by Sea, Journal of Mining Institute, vol. 233, iss. 1, pp. 554-560.

63. International Energy Agency (2019), Oil 2019 report, March. Available at: https://www.iea.org/reports/oil-2019 (accessed: 06.05.2020).

64. Radio Free Europe / Radio Liberty (2020), Trump says he brokered Saudi-Russia Oil deal but details scant, April 3. Available at: https://www.rferl.org/a/trump-says-he-brokered-saudi-russian-oil-deal-butdetails-scant/30526872.html (accessed: 06.05.2020).

65. Egan, M. (2020), Oil Prices turned negative. Hundreds of US Oil Companies could go Bankrupt, CNN, April 20. Available at: https://edition.cnn.com/2020/04/20/business/oil-price-crash-bankruptcy/index.html (accessed: 29.08.2020).

66. Oil Price Charts (2020), September 29. Available at: https://oilprice.com/oil-price-charts/ (accessed: 29.09.2020).

67. International Energy Agency. Oil Market Report - April 2020 (2020), April 30. Available at: https:// www.iea.org/reports/oil-market-report-april-2020 (accessed: 29.08.2020).

68. Morgunova, M. (2020), Why is exploitation of Arctic offshore oil and natural gas resources ongoing? A multi-level perspective on the cases of Norway and Russia, Polar Journal, vol. 10, iss. 1, pp. 64-81. https:// doi.org/10.1080/2154896X. 2020.1757823.

69. Voronkov, L. (2016), Russian Perspective on Asian Approaches to the Arctic, in Asia and the Arctic - Narratives, Perspectives and Policies, ed. by Sakhuja, V. and Narula, К. Место изд.? Springer Geology, pp. 115-124.

70. Sinha, U. K. (2013), The Arctic: an Antithesis, Strategic Analysis, vol. 37, no. 1, pp. 38-39.

71. Sinha, U.K. (2019), India in the Arctic: a multidimensional approach, Vestnik SPbGU. Seriia Mezhdunarodnye otnosheniia, vol. 12, iss. 1, pp. 113-126.

72. Voosen, P. (2020), New feedbacks speed up the demise of Arctic sea ice, Science, vol. 369, no. 6507, pp. 1043-1044.

73. SIMIP Community. Arctic Sea Ice in CMIP6 (2020), Geophysical Research Letters, vol. 47, iss. 10, pp. 1-11.

74. United States National Snow and Ice Data Center (2020), Arctic Sea Ice stalls out at second lowest minimum, September 21. Available at: https://nsidc.org/arcticseaicenews/2020/09/arctic-sea-ice-declinestalls-out-at-second-lowest-minimum/ (accessed: 29.09.2020).

75. Ghosh, S. (2020), India's Polar Missions Hit Pause, May 3. Available at: https://thenewleam. com/2020/05/indias-polar-missions-hit-pause/ (accessed: 29.05.2020).

Author's information:

Jawahar Bhagwat — PhD, Associate Professor; jawahar.bhagwat@gmail.com 